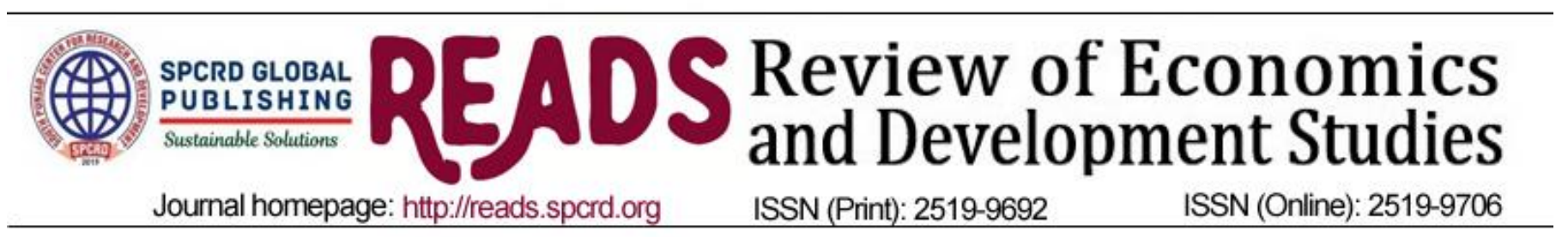

\title{
An Empirical Study on Students' Satisfaction from Mawlana Bhashani Science \& Technology University, Bangladesh
}

\section{${ }^{\text {a }}$ Mohima Akter, ${ }^{\mathrm{b}}$ Md Nazmus Sadekin, ${ }^{\mathrm{c}}$ Ataul Karim Patwary}

${ }^{a}$ Department of Economics, Mawlana Bhashani Science and Technology University, Santosh, Bangladesh Email: mohimaakter142@gmail.com

${ }^{\mathrm{b}}$ Department of Economics, Mawlana Bhashani Science and Technology University, Santosh, Bangladesh Email: sadekino8@gmail.com

c School of Tourism, Hospitality and Event Management, Universiti Utara Malaysia, Sintok, Kedah, Malaysia Email: raselataul@gmail.com

\begin{tabular}{|c|c|}
\hline ARTICLE DETAILS & ABSTRACT \\
\hline History: & \multirow{12}{*}{$\begin{array}{l}\text { The main motive of this study is to explore university canteen } \\
\text { foodservice attributes (food quality, food variety, price fairness, } \\
\text { ambience, staff, and student satisfaction)in Mawlana Bhashani Science \& } \\
\text { Technology. Data are accumulated through a simple random sampling } \\
\text { technique. A total of } 355 \text { numbers of valid questionnaires is used for } \\
\text { statistic exploration. For measuring the performance of all factors for } \\
\text { student satisfaction, } 7 \text { points Likert Scale is used.Qualitative\& } \\
\text { quantitative systems are used in the paper. Microsoft Excel version 1o.o, } \\
\text { Smart PLS software version 3.o, SPSS software version 2o.o, is } \\
\text { performed to analyze and test the theoretical model. Following the } \\
\text { literature, data are analyzed using Crosstab Analysis, Pearson } \\
\text { Correlation Coefficients, Structural Equation Modeling; Confirmatory } \\
\text { Factor Analysis, and Path Analysis. The findings show that food quality, } \\
\text { food variety, ambience \& staff have a significant positive influence on } \\
\text { student satisfaction, and the price has a negative impact on student } \\
\text { satisfaction. }\end{array}$} \\
\hline Accep & \\
\hline 2020 & \\
\hline Key & \\
\hline & \\
\hline Ambience (AMB), Staffs (STA), & \\
\hline Student satisfaction (SS), & \\
\hline Structural Equation Modeling & \\
\hline & \\
\hline Science and Technology (MBSTU) & \\
\hline & \\
\hline & \\
\hline
\end{tabular}

DOI: $10.47067 /$ reads.v6i2.215

(C) 2020 The authors. Published by SPCRD Global Publishing. This is an open access article under the Creative Commons AttributionNonCommercial 4.0

Corresponding author's email address: raselataul@gmail.com

\section{Introduction}

Thinking about food reminds people of two things. One is 'taste', and the other is 'need'. Firstly, the food satisfaction of people from different countries varies in their taste. They maintain their nutrition according to their food taste. In a few countries, like India, China, Colombia, Sri Lanka, Korea, Jamaica, Mexico, Laos, Indonesia prefers to have spicy food (Kiprop, 2018). And, few countries like to have non-spicy food, such as Pakistan and several Arabian countries. Most of the people are meat-lover, and few are vegetarian. So, the food satisfaction of the people across the world mostly depends on their 


\section{Review of Economics and Development Studies, Vol. 6 (2) 2020, 363-379}

taste. But it is not limited in just taste. When people think about any individual country which is mostly underdeveloped or developing countries, it needs to talk about the need. In a few countries, like Somalia, Nigeria, South Sudan, Mali, Bangladesh, many people of these countries can hardly have three times meal. Their satisfaction depends on their regular meal which they can hardly achieve. They cannot think about even their health. Food is an integral part of life. Food satisfaction cannot be described with one definition. In simple words, food satisfaction in the form of pleasure which comes not only taste but also needs. It varies across the world, among the individuals of the country. Satisfaction with food-related life is defined as a person's overall assessment regarding his or her food and eating habits (Schnettler et al., 2017). Food satisfaction enriches life in every way. A proverb goes on 'Health is wealth'. It does not only refreshes the mind of a person but also helps him/her to concentrate on education, family life \& job fields as well.

Sulek and Hensley (2004) find the significance of food quality, physical settings \& service in a full-service restaurant and reports that food quality appears to be the most important indicator of customer satisfaction although food quality describes only $17 \%$ of repeat-patronage intention (Namkung \& Jang, 2007). In one study which is conducted in Amritsar and Jalandhar of India, it is found that $15.3 \%$ people have their meal from branded restaurants, $23.3 \%$ people take food from fast food outlets and the rest $61.4 \%$ people use other shops or like to have food from their own home (Kumar \& Bhatnagar, 2017). Though the statistical studies of satisfaction related to the food of different countries, people are hardly found, a standard measure can be emphasized of satisfaction. Through figure 1, it can be said that after satisfying the hunger, completing the nutrition, a person will think to fulfil their satisfaction.

\section{HUNGER \& SATISFACTION GUIDE}

\section{LET YOUR BODY BE YOUR GUIDE}

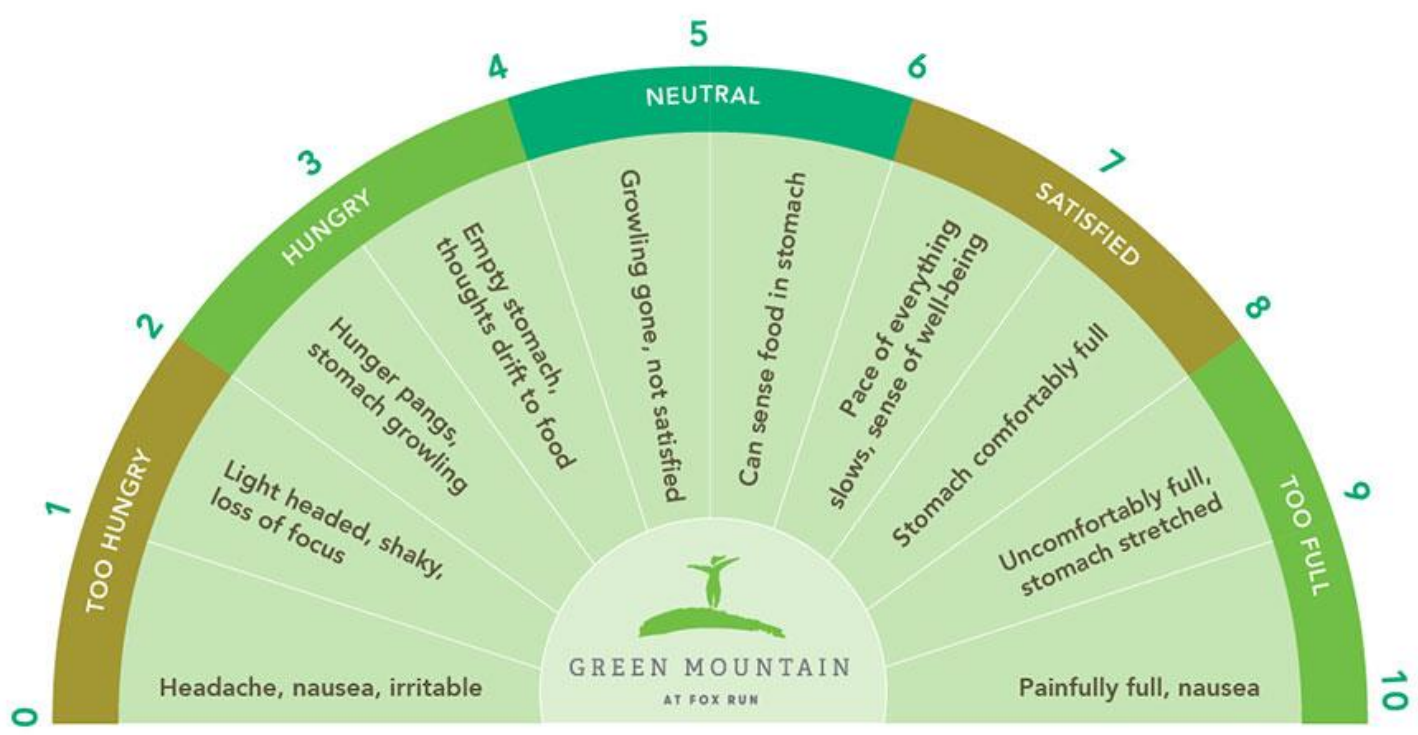

Individual appetite cues can vary and these are just suggestions. Explore how your body informs you.

Concept adapted from Learning/Teaching Handout Series CD on Eating Disorders. Sondra Kronberg, MS, RD, CEDRD. Wellness Publishing. 2001,

Figure 1: Hunger \& Satisfaction Guide

So say that the quality of food \& satisfaction varies among the world countries. Developed countries' food pattern shows in fulfilling students' expectations compelling variables are food \& 
beverage quality, price \& value fairness, food taste, nutrition, comport, assortment, convenience \&operating hours.

In the university area, students mostly gather in the campus canteen to have their meals. Serving healthy and nutritious food at a reasonable price in the campus canteen is essential. For the time being, the number of students registered in universities is increasing continuously, causing increase demand and constant rivalry between food service providers inside \& outside of the university (Garg, 2014; Patwary, Omar, \& Tahir, 2020). Consequently, the evaluation of university food services becomes essential (Knutson, 2000; Andaleeb \& Caskey, 2007). Eunkyung et al. (2013) and Dimitrios and Katerina (2014) underline that students' satisfaction in the university cafeteria highly depends on food quality, staff, and ambience. Presently, Mawlana Bhashani Science \& Technology has various challenges that need to be addressed, especially in terms of its canteen service quality provided to students'. For instance, a lot of students complain about the quality of food, variety of food display, physical environment \& service quality in the canteen. Hence, evaluating the students' food satisfaction at MBSTU, where the findings would serve as a feedback mechanism for providing pleasant \& satisfying canteen services. This study aims to investigate the total dining experience measuring behavioural characteristics of university students', and perceptions of different food service attributes and evaluate the most significant factors which have an impact on student satisfaction on food and beverage attributes on-campus canteen. The study also attempts to find out the combination of price fairness, quality of food, food variety, ambience, and staff for student satisfaction.

\section{Literature Review}

\subsection{Students' Satisfaction Drivers' in University Foodservice Canteen}

Greater satisfaction with food-related life positively associated with higher levels of life satisfaction \& happiness (Schnettler et al., 2015; Sadekin, Ali, \& Islam, 2018a; Sadekin, Aktar, \& Pulok, 2014; Sadekin, Ali, \& Islam, 2018b). The customer experience of food, service, price, and healthfulness significantly affected customer satisfaction levels and behaviour (Nasir \& Morgan, 2017). There is a positive consequence of satisfaction on loyalty, behavioural intentions, and switching costs (Prayag, Hassibi, \& Nunkoo, 2019). Quality of food \& beverages, services, value, price, hygiene and cleanliness, location, and food variety influence students' satisfaction ( $\mathrm{Ng}, 2005$; Patwary \& Rashid, 2016; Alom, Patwary, \& Khan, 2019). Food and beverage quality features, for example, cleanliness, quality \& menu variety price and value fairness are viewed as vital by university students and staffs eating at the cafeteria (Herrmann, Xia, Monroe, \& Huber, 2007; Mar- tin-Consuegra, Molina, \& Esteban, 2007; Oliver \& Swan, 1989; Patwary, Roy, Hoque, \& Khandakar, 2019; Patwary, Mohammed, Hazbar, \& Kamal, 2018). Five factors will be investigated concerning their impact on student satisfaction for the motive of the current study: price fairness, food, and beverage quality, food variety, ambience, and staff.

\section{Theoretical Underpinning}

Jerry (1972) develops the Cue Utilization Theory. This theory mainly focused on intrinsic and extrinsic cues to help the customers to evaluate the quality of any products. As a consequence, customer satisfaction is determined based on the quality assessment. In this study, food quality, food variety, ambience \& staff are reflected as intrinsic cues \& price fairness is indicated as an extrinsic cue for determining student satisfaction.

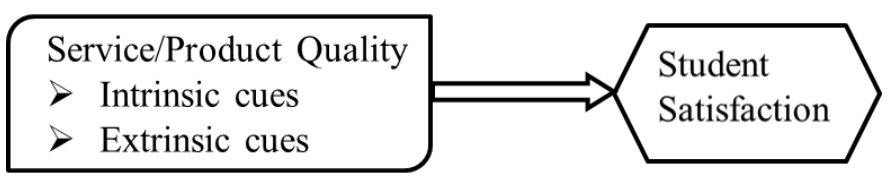




\section{Review of Economics and Development Studies, Vol. 6 (2) 2020, 363-379}

Figure 2: The cue utilization theory of student satisfaction Source: Jerry, (1972)

\section{Hypothesis Development}

\subsection{Price Fairness}

Mui et al. (2014) show that improving the food quality and price for long term sustainability the university cafeteria should take serious measurements. Klassen, Trybus, and Kumar (2005) and Nadzirah, Ab-Karim, Ghazali, and Othman (2013) find that as students buy food on limited funds, so the price is the first student concern in university foodservice. They were receiving the right value for the money paid to encourage customers to revisit a food service establishment (Azim, Tarannum, \& Patwary, 2017; Li, 2008; Yuksel \& Yuksel, 2002). Xi and Shuai (2009) show that student satisfaction with the cafeteria foodservice establish when price occurs somewhat. Thus, H1 is formulated as:

H1: There is a significant positive relationship between price fairness and students' overall satisfaction.

\subsection{Food Quality}

According to Peri, "Food quality is a necessary condition to satisfy the needs and expectations of customers." Food and beverage quality such as taste, smell, appearance, size, shape, colour, gloss, consistency, and texture are the acceptable quality property for customers (Imram, 1999; McWilliams, 2000; Patwary \& Omar, 2016). Oh (2000) finds a relationship between consumer satisfaction with food and beverage quality and his/her intention to return to a specific restaurant. (Namkung \& Jang, 2007) reveals customer satisfaction and behavioural intentions significantly affected by the overall food quality. (Nor et al., 2016) find the relationship between food quality attributes and customer satisfaction is statistically significant. $\mathrm{Ng}$ (2005) explains that price, value, convenience, and cleanliness are less important attributes than food quality attributes (taste, freshness, and appearance). Thus, $\mathrm{H} 2$ is formulated as:

H2: There is a significant and positive relationship between food and beverage quality and students' overall satisfaction.

\subsection{Food variety}

$\mathrm{Xi}$ and Shuai (2009) find that student satisfaction significantly influenced by food variety. (Ryu et al., 2008; Islam \& Patwary, 2013) postulate that food variety is the predictor of customer satisfaction. Ahmed et al. (2017) state menu variety is the predictor of customer satisfaction. Thus, $\mathrm{H}_{3}$ is formulated as:

H3: There is a significant positive relationship between food variety and overall student satisfaction.

\subsection{Ambience}

Troye et al. (1995) define ambience as a structural element. (Baker et al., 1994; Rys et al., 1987) say ambience is one of the fundamental indications to customers judging restaurant quality. Atmosphere and cleanliness are significant variables that have an impact on student satisfaction (Andaleeb \& Caskey, 2007; Patwary, 2017). Physical setting influences customers' perceptions of service quality (Norhati and Hafisah, 2013). Thus, $\mathrm{H}_{4}$ is formulated as:

H4: There is a significant positive relationship between ambience and student satisfaction.

\subsection{Staffs}

Barlett and Han (2007) show that the interaction between the canteen staff and the student is 
important as it influences student satisfaction. The staff performance is significant at each food outlet as it is increasing the degree of customer satisfaction (Mui et al., 2014). Thus, $\mathrm{H}_{5}$ is formulated as:

H5: There is a significant positive relationship between staff and student satisfaction.

\section{Research Design}

Research design presents the research design, sampling technique, research model research instrumentation measurement, data collection procedure\& statistical analysis.

\subsection{Research Design, Sampling Technique}

A self-report experience through a survey questionnaire is developed to obtain the required data. A simple random sampling technique is used for the data collection. Using the following formula by Krejcie \& Morgan (1970), the sample size is determined.

$$
n=\frac{\chi 2 N ~ P(1-P)}{e^{2}(N-1)+\chi 2 P(1-P)}
$$

Here,

Population size, $\mathrm{N}=5671$

At 95\% Confidence Level Chi-square value with degrees of freedom, one is, $\chi^{2}=3.841$

Population proportion, $\mathrm{P}=0.5$

Margin of error at 95\% Confidence Level, e = 0.05

At the given conditions the sample size is approximately 359.79 or 360

\subsection{Research Proposed Model}

Based on the literature review, the research proposed model of the study is illustrated in the figure below:

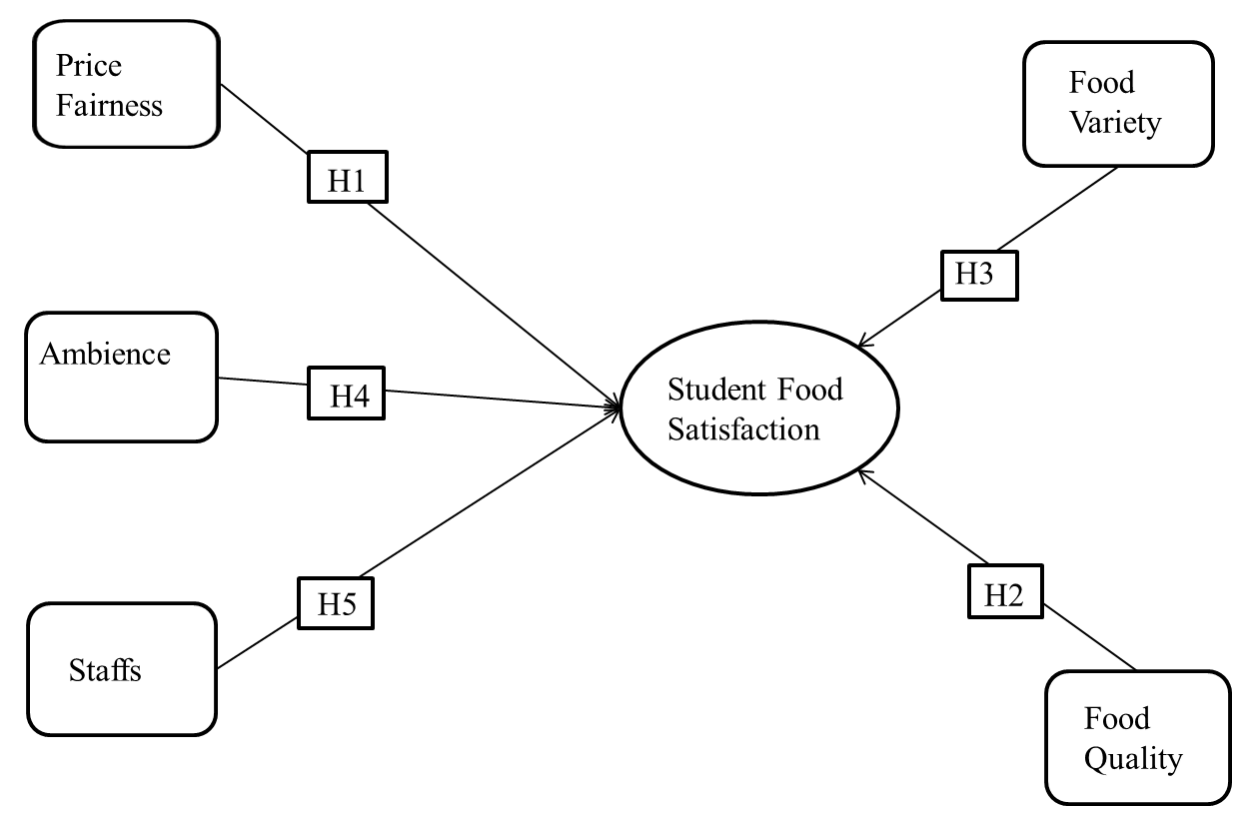

Figure 3: Research Proposed Model

Figure 3 shows the proposed model which conceptualizes the relationship among the factors of 
Review of Economics and Development Studies, Vol. 6 (2) 2020, 363-379

student satisfaction, price fairness, food quality, food variety, ambience \& staff. Here, in this proposed model, student satisfaction is a dependent variable, whereas price fairness, food quality, food variety, ambience, and staff are the independent variables.

\subsection{Research Instrumentation, Measurement \& Data Collection Procedure}

The 7 points Likert Scale (Strongly disagree to strongly agree) is used to measure the constructs. A total of 360 structured questionnaires are distributed, out of which 355 are received from the respondents.

\subsection{Statistical Analysis}

For this study, hypotheses are tested with SEM using PLS. Bootstrapping is applied to determine the significance level of the loadings, weights, and path coefficients.

\section{Result Analysis \& Discussion}

In this study, Descriptive Statistics such as Frequency Distribution\& Crosstabs Analysis have been applied to show Demographic Profile \& to investigate the difference of students' satisfaction according to their gender \& foodservice attributes of the students where several graphical presentations are used. After using Smart PLS 3.0; SEMEstimations are completed for testing the hypotheses.

\begin{tabular}{|l|c|c|}
\hline \multicolumn{3}{|c|}{ Table1: Percentage Distribution of Gender of the Respondents } \\
\hline Gender & Frequency & Percentage (\%) \\
\hline Male & 203 & 57.2 \\
\hline Female & 152 & 42.8 \\
\hline Total & 355 & 100.0 \\
\hline
\end{tabular}

Data source: Author

Table 1 shows the male respondents are 57.2 \%and female respondents.

\begin{tabular}{|l|c|c|}
\hline \multicolumn{3}{|l|}{ Table2: Percentage Distribution of Current Residence of the Respondents } \\
\hline $\begin{array}{l}\text { Current } \\
\text { Residence }\end{array}$ & Frequency & Percentage (\%) \\
\hline Hall & 230 & 64.8 \\
\hline Mess & 93 & 26.2 \\
\hline At Home & 32 & 9.0 \\
\hline Total & 355 & 100.0 \\
\hline
\end{tabular}

Data source: Author

Table 2 shows $42.8 \%$ among male and female $64.8 \%$ live in the hall, $26.2 \%$ live in a mess, and $9 \%$ live at home.

\subsection{Descriptive Statistics}

For the fulfilment of objective 01 following frequencies, percentage \& mean analyses are given below within table \& figure.

\begin{tabular}{|l|l|l|l|c|c|c|c|}
\hline \multicolumn{6}{|c|}{ Table3: Behavioral characteristics of the respondents on taking food items } \\
\hline $\begin{array}{l}\text { Cafeteria } \\
\text { Visiting time }\end{array}$ & Everyday & $\begin{array}{l}\text { Two or } \\
\text { three } \\
\text { times a } \\
\text { week }\end{array}$ & $\begin{array}{l}\text { Once a } \\
\text { week }\end{array}$ & Occasionally & $\begin{array}{l}\text { Doesn't } \\
\text { consume }\end{array}$ & $\begin{array}{l}\text { Total } \\
\text { Breakfast }\end{array}$ \\
\cline { 1 - 8 } & Lunch & 42.2 & 27.0 & 18.4 & 12.4 & 0.0 & 100 \\
\hline Dinner & 50.2 & 24.4 & 13.5 & 7.3 & 21.9 & 100 \\
\hline
\end{tabular}


Data source: Author

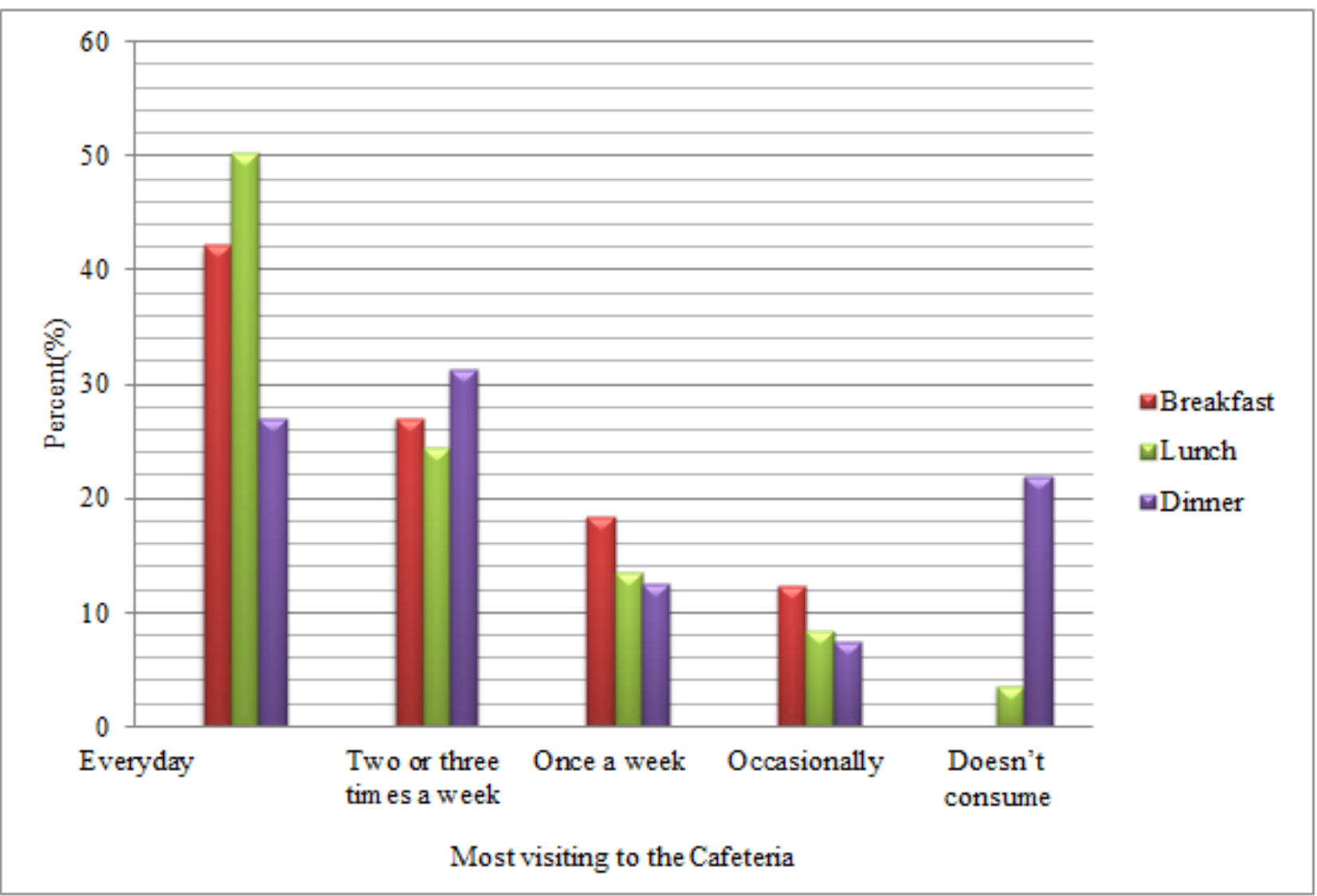

Figure 4:Behavioral Characteristics of the respondents on taking food items

In terms of behavioural meal consumption Table 3 and Figure 4 can be seen the highest proportion $(42.20 \%)$ of the students have daily breakfast \&lunch daily $(50.40 \%)$ and $(31.30 \%)$ have dinner two or three times per week in the canteen. The highest proportion did not have dinner (21.90\%) whereas $26.90 \%$ have dinner daily in the canteen.

Table 4: Behavioral characteristics of the respondents with foodstuff \& Soft drink

\begin{tabular}{|c|c|c|c|c|c|c|}
\hline \multicolumn{2}{|c|}{$\begin{array}{l}\text { Most Visiting time } \\
\text { to the cafeteria }\end{array}$} & $\begin{array}{l}\text { Fast } \\
\text { Food }\end{array}$ & $\begin{array}{l}\text { Soft } \\
\text { Drink }\end{array}$ & $\begin{array}{l}\text { Fish \& } \\
\text { Vegetables }\end{array}$ & Meat & Total \\
\hline Everyday & \multirow{5}{*}{ 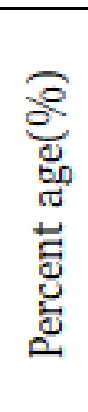 } & 28.1 & 16.0 & 24.6 & 31.3 & 100 \\
\hline $\begin{array}{l}\text { Two to three } \\
\text { times a week }\end{array}$ & & 28.2 & 22.1 & 19.4 & 30.3 & 100 \\
\hline Once a week & & $33 \cdot 3$ & 26.7 & $3 \cdot 3$ & 36.7 & 100 \\
\hline Occasionally & & 30.9 & 12.0 & 16.4 & 40.7 & 100 \\
\hline $\begin{array}{l}\text { Doesn't } \\
\text { consume }\end{array}$ & & 0.0 & 41.7 & 0.0 & 58.3 & 100 \\
\hline
\end{tabular}


Review of Economics and Development Studies, Vol. 6 (2) 2020, 363-379

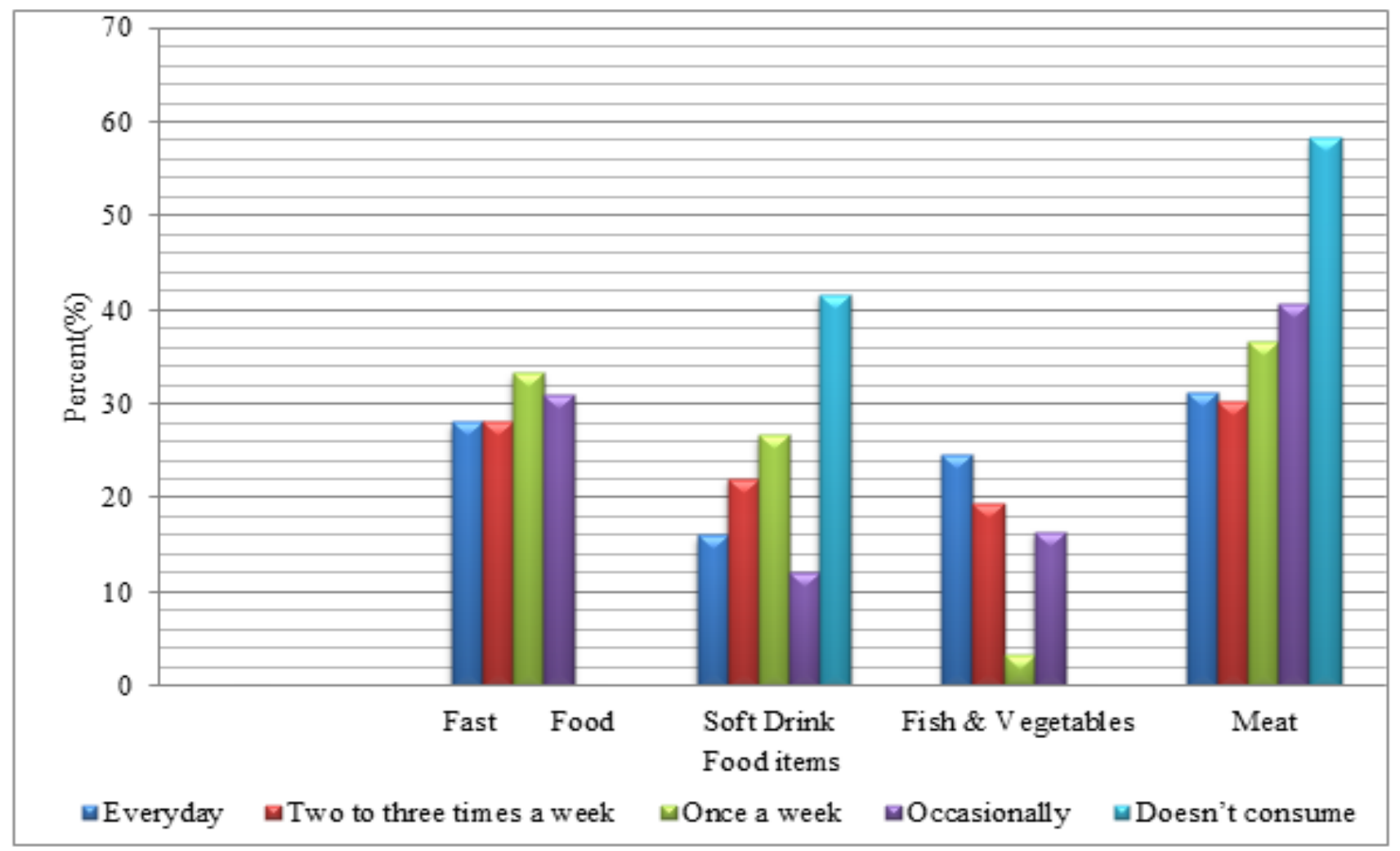

Figure 5: Behavioral characteristics of the respondents with food stuff \& Soft drink

In terms of Behavioral consumption of food staffs and soft drink Table, four and Figure 5 shows most of the students consume meat occasionally (40.70\%), once a week (37.70\%), 2 or 3 times a week (33.30\%), fish\&vegetables everyday $(24.60 \%)$, fast food daily $(26.10 \%)$, occasionally (30.90\%) or 2 or 3 times per week, soft drink daily $16.00 \%, 2$ or 3 times a week $22.10 \%$. 


\begin{tabular}{|c|c|c|c|c|c|c|c|c|}
\hline Variables & 1 & 2 & 3 & 4 & 5 & 6 & 7 & Mean \\
\hline Whatever price & $9 \cdot 3$ & 12.1 & 11.3 & 18.9 & 22.3 & 18.6 & 7.6 & 4.19 \\
\hline Acceptable price & $15 \cdot 5$ & 16.9 & 10.4 & 12.1 & 20.0 & 20.5 & $4 \cdot 5$ & 3.84 \\
\hline Changeable price & 13.0 & $17 \cdot 7$ & 9.6 & 18.9 & 20.8 & 14.9 & 5.1 & 3.82 \\
\hline $\begin{array}{l}\text { Overall mean for price } \\
\text { fairness }\end{array}$ & & & & & & & & $3 \cdot 95$ \\
\hline Food freshness & $5 \cdot 4$ & 10.7 & 11.3 & 18.5 & 19.7 & 25.6 & 8.7 & 4.48 \\
\hline Hot food & 7.0 & 7.0 & 5.1 & 7.9 & 23.1 & 38.6 & 11.3 & 4.94 \\
\hline Flavour of food & 7.0 & 7.0 & 11.0 & 10.7 & 28.2 & 29.0 & & $4.5^{8}$ \\
\hline Delicious food & 15.6 & 16.9 & 11.3 & 1.5 & 19.4 & 20.6 & & 3.83 \\
\hline Overall mean for food quality & & & & & & & & 4.46 \\
\hline Available food choices & $13 \cdot 5$ & 17.2 & 10.4 & 19.2 & 20.6 & 14.6 & 4.5 & 3.78 \\
\hline Special meals \& promotions & $9 \cdot 3$ & 12.1 & 11.8 & 18.3 & 22.3 & 19.2 & 7.0 & 4.18 \\
\hline Dietary food & 14.9 & 16.1 & 11.0 & 13.2 & 19.2 & 20.8 & 4.8 & 3.87 \\
\hline Overall mean for food variety & & & & & & & & 3.94 \\
\hline Hand wash facilities & 13.0 & $17 \cdot 7$ & 10.4 & 19.2 & 19.7 & 14.6 & 5.4 & 3.80 \\
\hline Comfortable seat & 9.3 & 12.1 & 10.7 & 17.2 & 23.4 & 20.3 & 7.0 & 4.22 \\
\hline Cleanliness & 2.5 & 5.9 & 4.5 & $15 \cdot 5$ & 38.3 & $27 \cdot 3$ & $5 \cdot 9$ & 4.87 \\
\hline Opening hours & 4.5 & 4.8 & 6.8 & 20.3 & 37.5 & 22.5 & $3 \cdot 7$ & 4.64 \\
\hline Noise & 6.5 & 6.8 & $13 \cdot 5$ & 23.1 & 20.6 & 23.7 & 5.9 & $4 \cdot 39$ \\
\hline Overall mean for ambience & & & & & & & & $4 \cdot 3^{8}$ \\
\hline Staffs hygiene & 4.8 & 6.8 & 6.5 & 23.7 & 20.3 & 30.4 & 7.6 & 1.66 \\
\hline Easy to talk & 13.5 & 16.6 & 10.4 & 19.7 & 19.2 & 14.6 & 5.9 & 2.43 \\
\hline Smiling \& greetings & $9 \cdot 3$ & 12.1 & 11.8 & 18.3 & 22.3 & 18.3 & $7 \cdot 9$ & 4.70 \\
\hline Efficiency of employees & 6.5 & 6.8 & 13.0 & 22.5 & 21.1 & 23.4 & 6.8 & 3.84 \\
\hline Overall mean for staffs & & & & & & & & 4.19 \\
\hline
\end{tabular}

Data Source: Author

Table 5 shows students' overall perceptions which are expressed with mean value at descending order. The overall mean rating scale is overall mean for the food, and beverage quality is $(\mathrm{M}=4.46)>$, Overall satisfaction for the ambience $(M=4.38)>$, overall mean for the student satisfaction is $(M=4.19)>$, price fairness $(M=3.95)>$ and Overall mean for the food variety is $(M=3.94)>$, and this overall result is measured using the research variables satisfaction level. 


\subsection{Correlation Analysis}

For the fulfilment objective, o2following correlation analyses are given below within a table.

\begin{tabular}{|l|c|c|c|c|c|c|}
\hline \multicolumn{7}{|c|}{ Table 6: Pearson Correlation Coefficients' Matrix } \\
\hline Variables & AMB & FQ & FV & PF & STA & SS \\
\hline AMB & 1.000 & & & & & \\
\hline FQ & $0.187^{*}$ & 1.000 & & & & \\
\hline FV & $0.328^{*}$ & $0.249^{*}$ & 1.000 & & & \\
\hline PF & $0.247^{*}$ & $0.420^{*}$ & $0.288^{*}$ & 1.000 & & \\
\hline STA & $0.252^{*}$ & $0.416^{*}$ & $0.278^{*}$ & $0.607^{*}$ & 1.000 & \\
\hline SS & $0.256^{*}$ & $0.417^{*}$ & $0.276^{*}$ & $0.609^{*}$ & $0.608^{*}$ & 1.000 \\
\hline
\end{tabular}

Note: *Correlation is significant at the 0.01 level (2-tailed)

Table 6 shows the results of correlation coefficients matrix correlation are significant at the 0.01 level \& no correlation coefficient is equal to 0.90 or above. This testing provides support for the discriminant validity, i.e. all the constructs are distinct (Amick \& Walbery, 1975). This correlation also indicates a strong positive relationship between the research variables.

\subsection{Regression Analysis}

For the fulfilment of objective 03 following model measurement results is given below:

\subsection{Measurement model}

Figure 6 demonstrates results' using PLS Algorithm technique for the hypothesized model is shown given below:

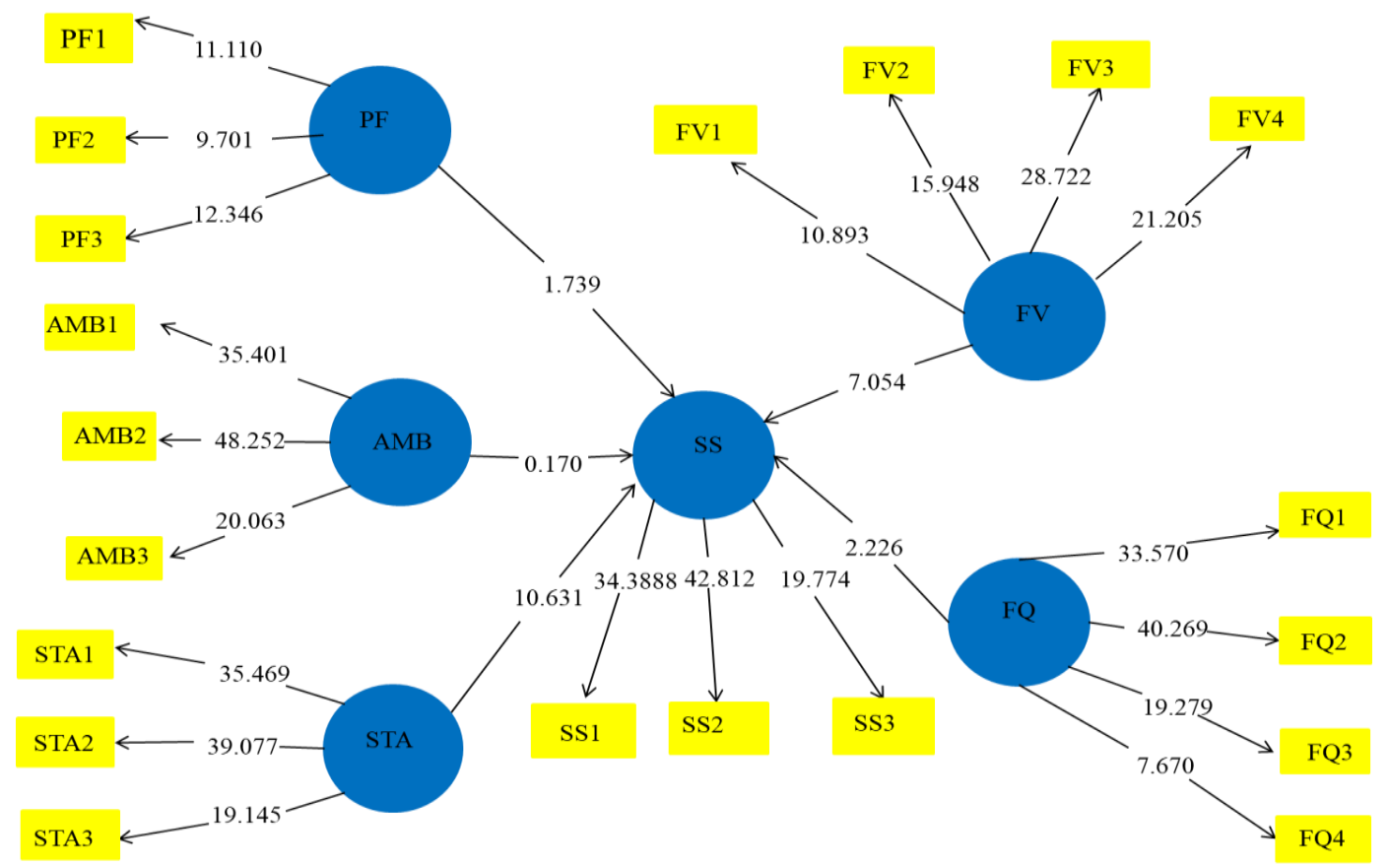

Figure 6: Hypothesized Model Structure \& Results 
Figure 7 demonstrates results using PLS Algorithm technique for the hypothesized model shown given below:

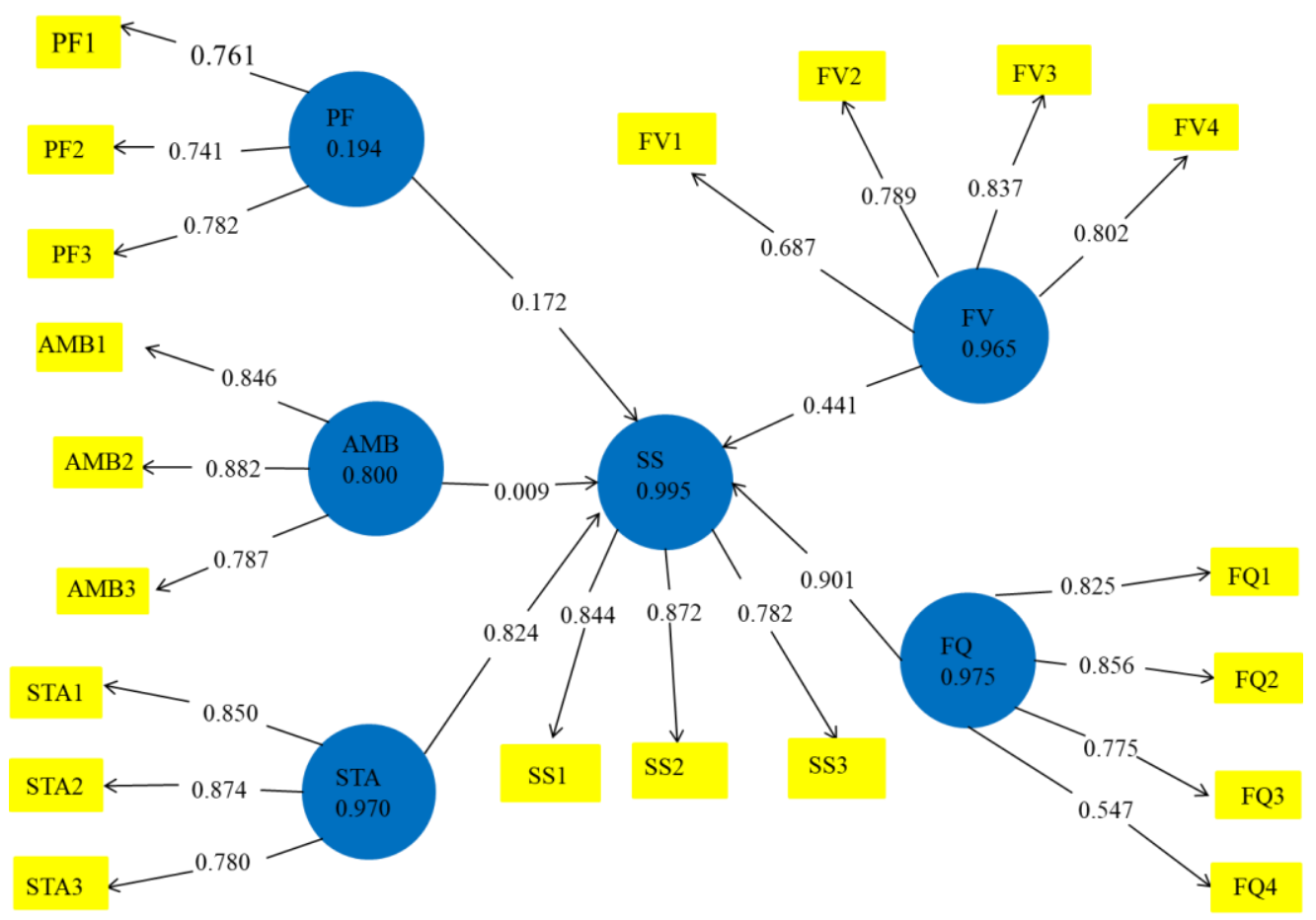

Figure 7: Hypothesized Model Structure \& Results

Hair et al. (2010) explain the lower limit value of Cronbach's alpha is o.6o. Composite reliabilities of constructs exceed the cutoff value of .70; which ensures adequate internal consistency (Hair, Anderson, Tatham, \& Black, 1998). Fornell and Larcker (1981) recommend that AVE explain variance, which has less than 50 per cent. Here in our analysis achieve these requirements see within Table7.

\begin{tabular}{|l|c|c|c|}
\hline \multicolumn{3}{|c|}{ Table 7: Coefficient \& Composite Reliability \& Validity Assessment } \\
\hline Factors & $\begin{array}{l}\text { Cronbach's } \\
\text { alpha }\end{array}$ & $\begin{array}{c}\text { Composite } \\
\text { Reliability }\end{array}$ & Average Variance Extracted(AVE) \\
\hline AMB & 0.651 & 0.805 & 0.580 \\
\hline FQ & 0.750 & 0.842 & 0.578 \\
\hline FV & 0.787 & 0.861 & 0.610 \\
\hline PF & 0.788 & 0.877 & 0.704 \\
\hline STA & 0.783 & 0.874 & 0.698 \\
\hline SS & 0.779 & 0.872 & 0.695 \\
\hline
\end{tabular}

Data Source: Author

Discriminant validity implies how well an individual item factor connects to its hypothesized construct in comparison to others (Osman, Sentosa et al. .2013). Table 8 demonstrates discriminant validity is measured via cross-loadings \& the square roots of AVE, which satisfies the above-mentioned criteria \& we termed discriminate validity as significant (Fornell \& Bookstein 1982). 


\begin{tabular}{|l|l|l|l|l|l|l|}
\hline \multicolumn{7}{|c|}{ Table 8: Discriminant Validity Fornell-Larcker Criterion } \\
\hline Factors & AMB & FQ & FV & PF & STA & SS \\
\hline AMB & 0.762 & & & & & \\
\hline FQ & 0.437 & 0.761 & & & & \\
\hline FV & 0.522 & 0.567 & 0.781 & & & \\
\hline PF & 0.402 & 0.977 & 0.456 & 0.839 & & \\
\hline STA & 0.413 & 0.976 & 0.443 & 0.989 & 0.836 & \\
\hline SS & 0.418 & 0.976 & 0.441 & 0.990 & 0.997 & 0.833 \\
\hline
\end{tabular}

Convergent validity is a scale's capability to come or load together as a single construct, and each loading is measured for another block of indicators (Osman, Sentosa, et al. 2013). The values of outer loadings should be greater than 0.7 , revealing that the indicators share more variance (LV) than with error variance. A lower limit of .50 may be acceptable (Chin, 1998). The value of convergent validity using the cross-loading matrix is given in Table 9, which fulfil the above-mentioned criteria

\begin{tabular}{|l|l|l|l|l|l|l|}
\hline \multicolumn{7}{|c|}{ Table 9: Outer Lodgings-Cross Loading Matrix } \\
\hline $\begin{array}{l}\text { Factor } \\
\text { s }\end{array}$ & AMB & FQ & FV & PF & STA & SS \\
\hline AMB1 & 0.846 & & & & & \\
\hline AMB2 & 0.882 & & & & & \\
\hline AMB3 & 0.787 & & & & & \\
\hline FQ1 & & 0.825 & & & & \\
\hline FQ2 & & 0.856 & & & & \\
\hline FQ3 & & 0.775 & & & & \\
\hline FQ4 & & 0.547 & & & & \\
\hline FV1 & & & 0.687 & & & \\
\hline FV2 & & & 0.789 & & & \\
\hline FV3 & & & 0.837 & & & \\
\hline FV4 & & & 0.802 & & & \\
\hline PF1 & & & & 0.761 & & \\
\hline PF2 & & & & 0.741 & & \\
\hline PF3 & & & & 0.782 & & \\
\hline STA1 & & & & & 0.850 & \\
\hline STA2 & & & & & 0.874 & \\
\hline STA3 & & & & & 0.780 & \\
\hline SS1 & & & & & & 0.844 \\
\hline SS2 & & & & & & 0.872 \\
\hline SS3 & & & & & & 0.782 \\
\hline
\end{tabular}

Data Source: Author

The predictability \& strength of a model is reflected by the $\mathrm{R}^{2}$ values, which are another vital determinant of the model (Chin1998). On the other hand, Adjusted $\mathrm{R}^{2}$ attempts to correct $\mathrm{R}^{2}$ to Adjusted $\mathrm{R}^{2}$. Chin et al. (2008) classify $\mathrm{R}^{2}$ values. Where $\mathrm{R}^{2}$ latent variables substantial $\left(\mathrm{R}^{2}=0.67\right)$, moderate $\left(\mathrm{R}^{2}\right.$ $=0.33)$, or weak $\left(\mathrm{R}^{2}=0.19\right)$. Table 10 represents this analysis which depicts the model as fitted \& satisfactory. 


\begin{tabular}{|l|l|l|}
\hline \multicolumn{3}{|c|}{ Table 10: $\mathrm{R}^{2}$ \& Adjusted $\mathrm{R}^{2}$} \\
\hline Factors & \multicolumn{1}{|c|}{$\mathrm{R}^{2}$} & AdjustedR \\
\hline AMB & 0.800 & 0.795 \\
\hline FQ & 0.975 & 0.975 \\
\hline FV & 0.965 & 0.965 \\
\hline PF & 0.194 & 0.190 \\
\hline STA & 0.970 & 0.970 \\
\hline SS & 0.995 & 0.995 \\
\hline
\end{tabular}

For testing research hypotheses, the bootstrapping technique of PLS-SEM is applied to generate the value of T-statistics, P-value to see whether these value support hypothesis or not. The level of confidence for the testing hypothesis is chosen to be 0.95; all hypotheses for which the significance number is outside the range -1.96 to 1.96 are supported. From Table 11, it appears that hypotheses are supported at a 5\% significance level \& Path coefficient with T-statistics which is larger than 1.96 where, $\mathrm{H}_{2}, \mathrm{H}_{3}, \mathrm{H}_{4}$ \& $\mathrm{H}_{5}$ are supported, and $\mathrm{H}_{1}$ is not supported. Value of T statistics of $\mathrm{H}_{1}$ is1.739, which is lower than the acceptance criteria 1.96 \& P-value is higher than 0.05. That's why this hypothesis is not supported.

\begin{tabular}{|l|l|l|l|l|l|}
\hline \multicolumn{5}{|c|}{ Table 11: Path Coefficients-Mean, STDEV, T-Values, P-Values } \\
\hline Factors & $\begin{array}{l}\text { Original } \\
\text { Sample }\end{array}$ & $\begin{array}{l}\text { Sample } \\
\text { Mean(M) }\end{array}$ & $\begin{array}{l}\text { Standard } \\
\text { Deviation(SD) }\end{array}$ & $\mathrm{T}^{*}$ & $\mathrm{P}^{* *}$ \\
\hline AMB->SS & 0.170 & 0.167 & 0.023 & 7.389 & $0.000^{\text {*t }}$ \\
\hline FQ->SS & 0.172 & 0.176 & 0.077 & 2.226 & $0.026^{\text {*t }}$ \\
\hline FV->SS & 0.441 & 0.044 & 0.062 & 7.054 & $0.000^{\text {*t }}$ \\
\hline PF->SS & 0.009 & 0.009 & 0.005 & 1.739 & $0.083^{\text {ns }}$ \\
\hline STA->SS & 0.824 & 0.819 & 0.077 & 10.631 & $0.000^{\text {*t }}$ \\
\hline
\end{tabular}

Note: ${ }^{*}$ the tabulated value of $\mathrm{t}=1.96,{ }^{* *}$ significant $=\mathrm{p}<0.05,{ }^{* *}=$ not significant

Table 12 shows a summary of hypothesis testing.

\begin{tabular}{|c|l|}
\hline $\begin{array}{c}\text { Table12: Hypothesis Testing } \\
\text { Summary }\end{array}$ \\
\hline Hypothesis No. & Declaration \\
\hline $\mathrm{H}_{1}$ & Not Accepted \\
\hline $\mathrm{H}_{2}$ & Accepted \\
\hline $\mathrm{H}_{3}$ & Accepted \\
\hline $\mathrm{H}_{4}$ & Accepted \\
\hline $\mathrm{H}_{5}$ & Accepted \\
\hline
\end{tabular}

\section{Discussion}

Following Table 11 and Table 12, hypothesis testing is interpreted. The hypothesis H1 is not accepted as the beta coefficient value is $0.009 \&$ insignificant at $\mathrm{p}<0.05$ level. This implies that students are not concern or probably they have satisfactory perceptions about food price. Several scholars (Nadzirah et al., 2013; Mui et al., 2014) also support this result. Hypothesis H2 is accepted since the beta coefficient 


\section{Review of Economics and Development Studies, Vol. 6 (2) 2020, 363-379}

value is 0.176 , and the value is less than 0.05 . The result is compatible with some former researchers ( Ng, 2008; Andaleeb and Caskey, 2007). Hypothesis $\mathrm{H}_{3}$ is accepted where the coefficient value is 0.004 , and the p-value is,p < 0.05. This result is consistent with several researchers (Garg \& Kumar, 2017; McCall and Lynn, 2008). Hypothesis $\mathrm{H}_{4}$ is accepted by the analysis as the outcome beta coefficients 0.313 , and the $\mathrm{p}$-value is significant at $\mathrm{p}<0.05$. This outcome is consistent with other researchers (Imran, 2018; Kumar \& Bhatnagar, 2017). The hypothesis $\mathrm{H}_{5}$ is accepted by the result of the beta coefficient value of $0.819 \mathrm{P}$ significant value level is $\mathrm{p}<0.05$ (Barlett \& Han 2007; Mui et al. 2014). Finally, these supportive results are fruitful for the students' food satisfaction to make a final canteen background.

\section{Conclusion}

This part displays a brief and extensive decision of the study result. Assessing different perceptions of food attributes the study reveals that among five dimensions of canteen food services four dimensions such as food quality, food variety, ambience, and staff have a significant positive impact on student food satisfaction. This result contributes to improving food and beverage outlets which are useful for student satisfaction.

At what time university neglect to take an interest in their general services faithfully, whereas frustrated students' might perceive the total product offered as below their expectations as food and beverage outlets can have a distinct impression. To retain students' retention university secretary can promote the manufacturing delivery and check students' food requirements.

Besides, confirming continual progress could be benefitted towards systematic arrangements for students' satisfaction. Providing cycle menu planning and fresh foods in the menu choices for a particular time, the university canteen administrators must take necessary steps. Attractive and pleasant ambience, staff training and development should be ensured. This study has significant classifications for university cafeterias, to take various enhancing directions and procedures.

\section{References}

Alom, S., Patwary, A. K., Khan, M. M. H. (2019). Factors Affecting the Turnover Intention of Bangladeshi Migrants in the United Arab Emirates: An Empirical Study on the Hotel Industry. International Journal of Innovation, Creativity and Change. 8 (3), 344-36o.

Amick, D. J. \& Walberg, H. J. (1975). Introductory Multivariate Analysis, California: McCutchan Publishing Corporation, ch. 7.

Andaleeb, S., \& Caskey, A. (2007). Satisfaction with food services: Insight from a college cafeteria. Foodservice Business Research Journal, 10(2), 51-65

Azim, M. S., Tarannum, L., \& Patwary, A. K. (2017). The Effects of Leadership Style into Fisheries Business Sector in Bangladesh. International Journal of Business and Technopreneurship, 7(1), 13-22.

Baker, J., Grewal, D., \&Parasuraman, A. (1994).The influence of store environment on quality inferences and store image.Journal of the Academy of Marketing Science, 22(4), 328-339.

Barlett, J. E., \& Han, F. (2007).Analysis of service quality in restaurants in China: An Eastern perspective. ABR \& TLC Conference Proceedings.

Chin, W.W. (1998). "Issues and opinions on structural equation modelling”.MIS Quarterly, Vol. 22 No. 1, pp. 7-16.

Chin, W.W., Peterson, R.A. and Brown, P.S. (2008). "Structural equation modelling in marketing: Some practical reminders”. Journal of Marketing Theory and Practice, Vol. 16 No. 4, pp. 287-98.

Dimitrios, P., \& Katrina, D. G. (2014). Critical factors, food quality management and organizational 


\section{Review of Economics and Development Studies, Vol. 6 (2) 2020, 363-379}

performance. Journal Food Control, 40(2014), 1-11

Eckel, P. J. (1985). College \& university foodservice management standards. 6, AVI Publishing Company.

Eunkyung, J., Youngah, C., Nami, J., \&Ji-Young, Y. (2013).Comparison of students' foodservice satisfaction between Korea and US.Nutrition Research and Practice, 7(1), 66-71.

Fornell, C. and F. L. J. J. o. M. r. Bookstein (1982). "Two structural equation models: LISREL and PLS applied to consumer exit-voice theory." 19(4): 440-452.

Fornell, C., \& Larcker, D. F. (1981).Evaluating structural equation models with unobservable variables and measurement error. Journal of marketing research, 18(1), 39-50.

Garg, A. (2014). Machanic clues vs. humanic clues: Students' perception towards service quality of fast food restaurants in Taylor's University campus. Procedia-Social and Behavioral Sciences, 144(1), 164-175.

Grunert, K. (2015). Relationship between the domains of the Multidimensional Students' Life Satisfaction Scale, satisfaction with food-related life and happiness in university students Relación entre Los dominios de la escala multidimensional de satisfacción con la vida, sat. Nutricion Hospitalaria 31(6), 2752-2763.

Hair, J. F., Black, W. C., Babin, B. J., \& Anderson, R. E. (2010).Multivariate Data Analysis: A global perspective (7th ed.). Upper Saddle River: Pearson Education

Herrmann, A., Xia, L., Monroe, K. B., \& Huber, F. (2007).The influence of price fairness on customer satisfaction.Journal of Product \& Brand Management, 16(1), 49-58.

Imram, N. (1999). The role of visual cues in consumer perception and acceptance ofa food product.Nutrition \& Food Science, 99(5), 224-230.

Imran, K. (2018). Investigating university students' satisfaction with on-campus cafeteria services: an empirical study in perspective of private university. Asian Journal of Empirical Research, 8(6), 225-237. https://doi.org/10.18488/journal.1007/2018.8.6/1007.6.225.237

Islam, R., \& Patwary, A. K. (2013). Factors influencing to the policy and strategies used to disabled employment in hospitality industry. Advances in Environmental Biology, 2598-26o6.

Jerry, C. O. (1972). Product quality perception: A model of quality /cue utilization and an empirical test. An unpublished doctoral dissertation, Purdue University

Klassen, K., Trybus, E., \& Kumar, A. (2005).Planning food services for a campus setting.Hospitality Management, 24(1), 579-609.

Knutson, B. J. (2000). College students and fast food - How students perceive restaurant brands. Cornell Hotel and Restaurant Administration Quarterly, 41(3), 68-74

Krejcie, R. and Morgan, D.W. (1970) Determining Sample Size for Research Activities. Educational and Psychological Measurement, 30, 607-610

Kumar, S., \& Bhatnagar, D. (2017). Factors affecting customer satisfaction of food and beverage outletsA study of food and beverage outlets between Amritsar and Jalandhar. IOSR Journal Of Humanities And Social Science (IOSR-JHSS, 22(9), 65-71. https://doi.org/10.9790/o8372209066571

Lawrence, S. M., Glenn, G., \&Guarino, A. J. (2013).Applied Multivariate Research (2nd ed.). SAGE, USA.

Li, G. (2008). Difficulties facing university catering service work and responses. Service and Technology Information, 14, 72-73.

Martin-Consuegra, D., Molina, A., \& Esteban, A. (2007). An integrated model of price, satisfaction, and loyalty: An empirical analysis in the service sector. Journal of Product \& Brand Management, 16(7), 459-468.

McCall, M., \& Lynn, A. (2008). The effects of restaurant menu item descriptions on perceptions of quality, price, and purchase intention. Journal of foodservice business research, 11(4), 439-445.

McWilliams, M. (2000). Foods: Experimental perspectives (2nd ed). New York: Measure consumer satisfaction. Hospitality Research Journal, 17(2), 63-74. 


\section{Review of Economics and Development Studies, Vol. 6 (2) 2020, 363-379}

Mui, L. D. C., Norazah, M. S., \&Nalini, A. (2014).A structural approach on students' satisfaction level with university cafeteria.Asian Social Science, 10(18), 202-209.

Nadzirah, S., Ab-Karim, S., Ghazali, H., \& Othman, M. (2013). University foodservice: An overview of factors influencing the customers' dining choice. International Food Research Journal, 20(3), $1459-1468$.

Namkung, Y., \& Jang, S. C. (2007). Does Food Quality Really Matter in Restaurants? Its Impact On Customer Satisfaction and Behavioral Intentions. Journal of Hospitality and Tourism Research, 31(3), 387-409.https://doi.org/10.1177/1096348007299924

$\mathrm{Ng}, \mathrm{Y}$. (2005).Study of the impact of customer satisfaction on intention to return and return intention, and word-of-mouth endorsement in university dining operations. (Published master thesis) Oklahama, USA: Graduate College of Oklahoma State University, Stillwater.

Norhati, I., \&Hafisah, F. N. (2013). Informal setting for learning on campus: Usage and preference. Procedia-Social and Behavioral Sciences, 105(2013), 344-351.

Oliver, R. L., \& Swan, J. E. (1989). Consumer perceptions of interpersonal equity and satisfaction in transactions: A field survey approach. Journal of Marketing, 53(2), 21-35.

Osman, Z., et al. (2013). "Mediating effect of customer satisfaction on service quality and customer loyalty relationship in Malaysian rural tourism." 2(1): 25-37

Patwary, A. K., \& Omar, H. (2016). An overview of consumer complaining behavior and the choice of complaint channels in service industry. International Journal of Business and Technopreneurship, 6(2), 309-318.

Patwary, A. K., \& Rashid, B. (2016). The impacts of hospitality services on visit experience and future visit intention of student travelers. International Journal of Business and Technopreneurship, 6(8), 107-125.

Patwary, A. K., Mohammed, A. A., Hazbar, A. H., \& Kamal, N. S. B. N. (2018) Factors Influencing Consumers' Intentions towards Purchasing Islamic Hotel Service: Moderating Role of Religiosity. Economics, 5(7), 482-497.

Patwary, A. K., Omar, H., Tahir, S. (2020). A Conceptual Model of What Influences Consumers When Visiting Green Hotels in Malaysia. International Journal of Innovation, Creativity and Change, 11 (11), 11-25.

Patwary, A. K., Roy, B., Hoque, R., \& Khandakar, M. S. A. (2019). Process of Developing a Community Based Tourism and Identifying its Economic and Social Impacts: An Empirical Study on Cox's Bazar, Bangladesh. Pakistan Journal of Humanities and Social Sciences, 7(1), 1-13.

Patwary, A. K. (2017). The Influence of Socio-Demographic Factors in Domestic Tourists Complaining Constraints with Hotel Services. Published Masters Dissertation, Universiti Utara Malaysia.

Raman, S., \& Chinniah, S. (2011). An investigation on higher learning students satisfaction on food services at university cafeteria. Journal of Research in Commerce, IT \& Management, 1(2), 12-16.

Ringle, C. M., Wende, S., and Becker, J.-M. 2015. "SmartPLS 3." Boenningstedt: SmartPLS GmbH, http://www.smartpls.com.

Ryu, K., Han, H. and Kim, T.H. (2008) The Relationships among Overall Quick-Casual Restaurant Image, Perceived Value, Customer Satisfaction and Behavioural Intentions. International Journal of Hospitality Management, 27, 459-469.http://dx.doi.org/10.1016/j.ijhm.2007.11.001

Sadekin, M. N., Aktar, M. A., \&Pulok, M. H. (2014). Socioeconomic analysis of the migrated rickshaw pullers in Comilla City of Bangladesh. International Journal of Innovation and Applied Studies, 8(3), 1142.

Sadekin, M. N., Ali, J., \& Islam, R. (2018a). The Socio Demographic Status of Small Scale Fishers of Inland open Water Area: A Case Study from ChalanBeel Area of Bangladesh. International Journal of Engineering \& Technology (UAE), 7(4.28), 305-311.

Sadekin, M. N., Ali, J., \& Islam, R. (2018b). The Livelihood Strategies and Food Management of the 
Review of Economics and Development Studies, Vol. 6 (2) 2020, 363-379

Small-Scale Fishing Communities: A Case Study from Inland Open Water Area of Bangladesh. Journal of Economics and Sustainable Development, 9(22), 8-10.

Saglik, E., Gulluce, A., Kaya, U., \&Ozhan, Ç. (2014). Service quality and customer satisfac- tion relationship: A research in erzurumataturk university refectory. American International Journal ofContemporary Research, 4(1), 100-117

Schnettler, B., Miranda, H., Lobos, G., Orellana, L., Sepúlveda, J., Denegri, M., ... Grunert, K. G. (2015). Eating habits and subjective well-being. A typology of students in Chilean state universities. Appetite, 89, 203-214. https://doi.org/10.1016/j.appet.2015.02.008

Schnettler, B., Miranda-Zapata, E., Grunert, K. G., Lobos, G., Denegri, M., Hueche, C., \& Poblete, H. (2017). Life satisfaction of university students in relation to family and food in a developing country. Frontiers in Psychology, 8(SEP), 1-10. https://doi.org/10.3389/fpsyg.2017.01522

Sulek, J.M., \& Hensley, R.L., (2004). The relative importance of food, atmosphere, and fairness of wait.Cornell Hotel and Restaurant Administration Quarterly, 45 (3), 235-247.

Troye, S. V., Skalpe, O., Ogaard, T., Larsen, K. F., Henjesand, I. J., Kvitastein, O. A., \&Risholm, N. (1995). Investigation of customer satisfaction in student food service: An example of student cafeteria in NHH. The Economies of Service Quality, NHH, Bergen.

Xi, L., \& Shuai, Z. (2009).Investigation of customer satisfaction in student food service.An example ofstudent cafeteria inNHH.Quality and Service Sciences International Journal, 1(1), 113-124.

Yuksel, A., \& Yuksel, F. (2002). Measurement of tourist satisfaction with restaurant services: A segment based approach. Journal of Vacation Marketing, 9(1), 52-68. 